\title{
Joint Venture and Value Added Tax Regime. Common Law Rules versus Tax Law Rules
}

\author{
Associate Teacher Professor Doru PLEŞEA, PhD \\ Transilvania University of Braşov, Romania
}

\begin{abstract}
The overall economic situation considers a scenario that is not exactly optimistic in the context of the current health crisis. The need for cheap resources will probably lead to the seizing of the opportunities provided by the trade companies, without patrimonial transfers of goods and labour force. Taking this context into account, we believe that the mixed ventures might become relevant again nowadays. The challenge posed by the indirect taxation of these associations without legal personality points out a series of practical aspects which we consider that should be rigorously and thoroughly addressed, especially that the tax payers' option is not always in accordance with that of the fiscal authorities causing contentious issues, which are time and money consuming and at the same time lead to forced executions endangering the company's existence itself.

The article hereby is based on the material tax law rules as regards the common law provisions, with the aim of setting up the tax deductions regime regarding the contributions and purchases related to joint ventures, given that the Council Directive 2006/112/EC of 28 November 2006 on the common system of value added tax does not include specific provisions for joint ventures, which is why the jurisprudence of the Court of Justice of the European Union is applicable in this matter.
\end{abstract}

Key terms: joint venture, contributions with payment, contributions without payment, property transfer, deductible VAT, collected VAT

JEL Classification: L24, K15, K34

To cite this article: Doru Pleşea, Joint Venture and Value Added Tax Regime. Common Law Rules versus Tax Law Rules, CECCAR Business Review, No 1/2022, pp. 53-60, DOI: http://dx.doi.org/10.37945/cbr.2022.01.07

The joint venture agreement was in a first period of transition to the market economy the main legal instrument through which the former state economic units, which became trading companies, were able to cooperate with private entrepreneurs in order to enhance their unused assets. It is true, however, that it sometimes covered other legal relationships, which the venturers were either not authorized to conclude, in the absence of a public auction (rents or commercial leasing), or were not authorized to contract them (loans and other banking operations) (Ciutacu, 2001, p. 149).

The company agreement, in general, is regulated by the common law provisions contained in Articles 1881-1889 of the Law No. 287/2009 on the Civil Code, republished, as subsequently amended and supplemented, and the legal regime of the joint venture is characterized by the provisions contained in Articles 1949-1954 of the same normative act. Thus, according to Article 1949, "the joint venture agreement is the agreement by 
which a person grants to one or more persons a share in the profits and losses of one or more operations which it undertakes".

A definition of a joint venture was given by the High Court of Cassation and Justice as follows: "the joint venture has the improper nature of a company in which one person participates in the business of another to share the profits and losses with it. Whether it concerns a single trade operation or an entire trade, the association can also take place for the operations carried out by non-traders. Therefore, the city hall can be part of the association agreement, even if it is not a trader, because Article 252 of the Commercial Code (the Romanian Commercial Code was repealed by Article 230 of the Law No. 71/2011 for the implementation of the Law No. 287/2009 on the Civil Code) is explicit, in the sense that non-traders can also conclude such agreements." (Decision No. 713/2005 of the High Court of Cassation and Justice, Commercial Chamber), the solution being up-to-date in view of the possibility of any natural or legal person to participate in this form of company.

The joint venture is devoid of legal personality, according to Article 1951 of the Civil Code, and differs from the trading company by the absence of the characteristic elements of the latter: company, emblem, headquarters, nationality (Annotated Commercial Code, 1994, p. 294). The joint venture is considered an entity only in terms of competition law, in common law being devoid of the vocation to legal personality, as it is an agreement having as object the administration of one or more isolated businesses or of all commercial activities by the venturer. In the doctrine, due to the particularity of the lack of legal personality, the principle of legal independence of each venturer was laid down, keeping in mind that "there is no principal-agent or subordination relationship between the venturers, each venturer being free to carry out its activity according to its own rules" (Cărpenaru, 2009, p. 495).

The fiscal definition of the association is given by Article 7 Point 14 of the Law No. 227/2015 on the Fiscal Code, as subsequently amended and supplemented, establishing the rule that a transparent fiscal entity, with/without legal personality, is any association, joint venture, partnership based on joint venture agreements, economic interest group, civil society or other entity that is not a separate taxable person, each venturer/participant being subject to taxation within the meaning of the profit or income tax, as the case may be (the definition in the Fiscal Code of associations without legal personality must be correlated with the provisions of Articles 1949-1954 of the Civil Code).

As a subspecies of the company agreement (the legislator of the Civil Code places the joint venture within the company agreement, the general provisions provided for in Articles 1881-1884 being fully applicable to it), the contractual character of the joint venture results undoubtedly from the text of Article 1949 of the Civil Code, the same way as per the provisions of Article 1950 of the Civil Code it results that the written form is required only for proof of the agreement (ad probationem). Also, the onerous character of the agreement results from the purpose of concluding the association, aiming at obtaining profit by participating in the benefits of a certain operation, and the commutative character is determined by the fact that obtaining profit depends on good business management, not by chance. Undoubtedly, since the association takes place in consideration of one or more transactions, the joint venture may be a continuing contract or a call-off contract.

Fiscal practice in the application of civil law reveals some inconsistencies between the two codes: the fiscal code and the civil code. By way of example, the intertwining of the association agreement with the principle of proportionality corresponding to the contribution (intake) excludes the application of the freedom to contract guaranteed by the Civil Code. Thus, according to Article 125 Paragraph (5) of the Fiscal Code, "the annual income/loss realized within the association is distributed to the venturers in proportion to the percentage share of participation corresponding to the contribution, according to the association agreement", versus Article 1954 of the Civil Code, which provides the following: "except for the provisions of Articles 1949-1953, 
the parties determine the form of the agreement, the extent and conditions of the association, as well as the causes of its dissolution and liquidation".

We consider that regarding these inconsistencies, the Civil Code, as a superior organic rule, common law in the matter, cannot be modified by the Fiscal Code. In this respect, we bring as an argument both the provisions of Article 2 Paragraph (2) of the Civil Code, according to which this normative act "consists of a set of rules that constitute the common law for all areas referred to in the letter or spirit of its provisions", and the provisions of Article 3 Paragraph (2) of the Law No. 207/2015 on the Code of Fiscal Procedure, as subsequently amended and supplemented, according to which "where this Code does not provide, the provisions of the Civil Code and the Code of Civil Procedure, republished, shall apply, insofar as they may be applicable to the relations between public authorities and taxpayers/payers".

Based on these brief considerations, our purpose was to analyse the practical impact of the provisions of Article 321 Paragraph (5) of the Fiscal Code and Point 102 of the Government Decision No. 1/2016 for the approval of the Methodological Norms for the application of the Law No. 227/2015 on the Fiscal Code, as subsequently amended and supplemented.

\section{Example}

We will take as an example a joint venture where two trading companies, $A$ and $B$, have the same object of activity, namely mass production. The object of the association is the development of business by means of profitable activities, the parties bringing for this purpose, as the case may be, a contribution in money, goods or necessary services. The agreement states that in the production activity carried out jointly at the registered office of Party B the activity of canteen, shop, and other activities that are outside the scope of production carried out by $B$ does not fall within the object of the joint venture.

According to the contractual agreement, the obligations of the main venturer, $A$, appointed leader of the association, are the contribution of goods for the joint development of the activity in the association, the organization and management of the association's accounts, the determination of the net profit/loss obtained within the association, as well as the distribution of the net profit/loss on the venturers, representation of the association in the relations with the fiscal bodies, completion of the Register for the record of the contribution and the distributed result. The secondary venturer, B, is kept inter alia with the contribution of goods for the joint development of the activity in the association.

Regarding the contributions of the parties, the venturer A contributes for the accomplishment of the agreed common economic activities with raw materials, facilities, equipment, know-how, market, having the share of participation in the association in quota of $30 \%$, and the venturer B contributes with production halls, raw materials, equipment, labour force, utilities, having the share of participation in the association in quota of $70 \%$. Also, according to the contractual agreement, the main and secondary associations have the right to participate in the distribution of the profit made from the association, to participate in the distribution of the result in case of termination of the association, to regain full ownership over the goods it contributed with, to inform on the activities of the association, with the mention that the secondary venturer does not have a direct control over the administration carried out by the main venturer. At the same time, the venturer appointed leader will open a separate cash account for the collection and payment operations of the association and that all papers and supporting documents regarding the association, throughout its duration, will be archived at its headquarters.

From the perspective of the legal provisions in force and the terms of the joint venture agreement, we will analyse the deductibility of value added tax in connection with the purchases of goods/services related to the association made by the two parties, both registered for VAT purposes. 
Among other things, the venturer B purchases raw materials for the production carried out in association, and ensures, according to the understanding, the necessary utilities: electricity, water and thermal agent for heating the production halls in wintertime, taxable operations from the VAT point of view.

We will answer the question: Does the second venturer, $B$, have the right to deduct the value added tax entered in the invoices of the suppliers of purchases of raw materials and utilities related to the association?

First of all, we note the incidence of the provisions of Section 4.14 "Accounting of the operations performed within the joint venture agreements" from the Accounting regulations regarding the individual annual financial statements and consolidated annual financial statements, approved by the Order of the Minister of Public Finance No. 1802/2014, as subsequently amended and supplemented, according to which, among other things, the record of the joint venture is organized both at the level of the association and in the accounting of each co-participant using account 458 "Settlements from joint operations", analytical account distinct on each co-participant, and the company who keeps the records of the joint venture keeps records and draws up the trial balance distinct from those corresponding to its own activity. Also, regarding the tangible and intangible assets made available to the association, they are included in the accounting records of the owner and the expenses and income determined by the operations of the joint venture are accounted separately by one of the venturers, according to the provisions of the association agreement, following that at the end of the reporting period the expenses and income recorded by nature should be transmitted on the basis of a cost claim to each venturer, in order to record them in their own accounting.

From the very beginning we evidence that the provisions of Article 321 Paragraph (5) of the Fiscal Code leave no room for interpretation, the text being unequivocal, as follows: "In the case of joint ventures that do not constitute a taxable person, the rights and the legal obligations regarding the tax are incumbent on the venturer who accounts for the income and expenses, according to the agreement concluded between the parties.". In this example, these rights and obligations regarding VAT belong to the leading venturer, A, according to the contractual agreement.

Regarding the Methodological Norms for the application of the Fiscal Code we remind you that the Government decisions are adopted for the purpose of law enforcement, in the sense of regulating concrete and detailed ways of carrying out the measures provided by law, as required by Article 108 Paragraph (2) of the Constitution: "Decisions are issued for the organization of law enforcement.".

Thus, we draw attention to the fact that it is necessary to comply with the general rule according to which the rules adopted by secondary normative acts must include provisions in the execution of the provisions from the primary normative act. Also, the secondary normative act must not add to the law, in the sense of bringing a supplement to its overall conception, or to regulate legal relations that can only be regulated at the primary level.

We mention that in applying the provisions of Article 269 Paragraph (11) and Article 321 Paragraph (5) of the Fiscal Code, the Methodological Norms included in Point 102, with 18 paragraphs, were issued.

For the purposes of executing the provisions of Article 321 Paragraph (5) of the Fiscal Code, we consider to be inter alia the provisions of Paragraph (11) of Point 102 of the norms: "During the progress of the association agreement, the rights and legal obligations regarding the value added tax provided by Title VII of the Fiscal Code devolve upon the managing venturer, which also includes in its own tax return the purchases of goods/services, as well as the deliveries of goods/services related to the association. By legal rights and obligations is meant, among other things, the right to exercise the deduction of tax for purchases made for the purpose of the association, according to the provisions of Articles 297-301 of the Fiscal Code, the obligation to issue invoices to the beneficiaries and to collect the tax in the case of taxable transactions resulting from the association, the right/obligation to 
adjust the tax according to the provisions of Article 304, in the case of its own assets, and Article 305 of the Fiscal Code, both for its own capital assets and for those that were brought as a contribution to the association by the members of the association, and which are used for the purpose of the association.".

Secondly, we recall the provisions of Article 1949 and the following of the Civil Code, which shows that the lack of legal personality, but also the fact that it does not benefit from a common, autonomous patrimony, with its own name, own headquarters, and, consequently, cannot acquire its own rights or obligations, are specific to the joint venture. In this context, it is necessary to bear in mind that the legal rights and obligations regarding the value added tax provided by Title VII of the Fiscal Code belong to the managing venturer only after the conclusion of the association agreement, starting with its implementation. The second sentence of Paragraph (11) specifies in concrete terms what are these rights and obligations related to the exercise of the tax deduction for the purchases made to achieve the purpose of the association, referring to the conditions comprised in the provisions of Articles 297-301 of the Fiscal Code.

The two conditions selected and admitted including by the case-law of the contentious administrative courts are provided by Point 69 Paragraph (1) of Section 3 "Conditions for exercising the right of deduction" of the Methodological Norms for the application of the Fiscal Code: "The taxable person may deduct the tax related to the acquisitions if the substantive conditions provided in Point 67 Paragraph (1) are met, as well as the formalities provided in Article 299 of the Fiscal Code.".

Returning to our example, we will search for the reasoned answer on the legal provisions regarding the right to deduct VAT and including the reimbursement of the second venturer, B, for the purchases of raw materials and utilities related to the association.

From the outset, we reiterate the incidence of the provisions of Article 321 Paragraph (5) of the Fiscal Code, from which it results explicitly and with special force that the right to deduct the VAT belongs to the venturer who accounts for the income. With regard to the tax regime of joint ventures, it should be noted, first of all, that it does not give rise to a separate taxable person (subject of tax law), so that each venturer is considered a separate taxable person only for those economic activities which are not carried out on behalf of the association, pursuant to the provisions of Article 269 Paragraphs (9) and (10) of the Fiscal Code.

From the point of view of VAT, it is to be noted that the legal effects are borne by the venturer who accounts for income and expenses, in this case venturer $A$, who is required to draw up monthly defraying of expenses with the costs conducted, it draws up sales invoices for products sold and collect their value, so that in this case all the economic operations with the clients of the association are carried out through the accounting of this venturer. Given that the second venturer, B, does not have the right to collect and pay the VAT resulting from the economic operations of the association, it neither has the right to claim and obtain the deduction of VAT and the reimbursement of VAT.

To do otherwise would represent a breach of the principle of fiscal neutrality, according to which the VAT does not have to be a cost to the business. In the event that during the association agreement the right of deduction for the purchases of raw materials and utilities made by the second venturer related to the association does not belong to the first venturer, i.e. the one obliged to collect the tax and the one who fully registers the taxable operations of the association that results from the delivery of the jointly obtained production, would lead to the situation where for this VAT deducted by the partner would become a business cost with serious impairment of own cash flows.

In Case C-8/17, having as object a request for a preliminary ruling made under Article 267 TFEU from the Supremo Tribunal de Justiça (Supreme Court of Justice, Portugal), in the proceedings Biosafe - Indústria de Reciclagens SA versus Flexipiso - Pavimentos SA, the Court of Justice of the European Union (CJEU) it states 
that "the system of deductions seeks to relieve the entrepreneur entirely of the burden of VAT due or paid in the course of all his economic activities. Therefore, the common system of VAT guarantees the neutrality of the tax burden corresponding to all economic activities, regardless of their purpose or results, provided that those activities are, in principle, themselves subject to VAT (Ruling of March 21, 2018, Volkswagen, C-533/16, EU: C:2018:204, Point 38 and the case-law quoted).".

Suppose that the VAT collected by venturer A for the production obtained jointly with venturer B is $1,500,000$ lei, the former having the obligation to issue invoices to the beneficiaries and to collect the tax in case of taxable operations resulting from the association. The VAT entered in the invoices for the purchase of goods and services related to the association made by the venturer $A$ registered as deductible is 300,000 lei. The tax entered in the invoices for the purchase of goods and services related to the association made by the venturer $B$ registered as deductible is 450,000 lei.

If venturer A would deduct only its own tax entered in the invoices for purchases of goods and services related to the association, it would be obliged to pay the amount of 1,200,000 lei, representing payable VAT, and venturer $B$ would have to reimburse the amount of 450,000 lei but without being liable for the taxable transactions (it does not issue invoices to the beneficiaries and does not collect VAT in the case of taxable transactions resulting from the association), in accordance with Point 102 Paragraph (11) of the Methodological Norms. In the hypothesis, which we support by the way, in which it would deduct during the association agreement the amount of 450,000 lei entered in the invoices for purchases of goods and services related to the association made by the venturer B would be obliged to pay the amount of 750,000 lei representing payable VAT.

We also remind you that the generating fact represents the fact by which the legal conditions necessary for the eligibility of the tax are achieved and intervenes, according to the provisions of Article 281 Paragraph (1) of the Fiscal Code on the date of delivery of goods/performance of services.

Thus, at the time of consumption of raw materials and utilities for the purpose of obtaining production within the association, there is a transfer of ownership from venturer $B$ to venturer $A$ (raw materials and utilities incorporated in the production cost of the finished products obtained) for which by cost claim it is allocated the share of income corresponding to the purchased goods related to the association. We consider that from this moment the venturer $A$ appointed leader of the association becomes the owner of the production in progress in whose production cost are also included the expenses with raw materials and utilities made by the venturer $B$ (from the point of view of VAT equal to the taxable base identical to their purchase price). These products from the execution phase until the moment of delivery and implicitly the receivables arising from their sale to third parties are part of the patrimony of the leading venturer, A. As a legal entity holding a patrimony, $A$ has the right to dispose of these products (there are three indispensable elements for understanding the notion of patrimony: the rights and obligations that constitute the patrimony have economic value, they are pecuniary (assessable in money); these patrimonial rights and obligations form a legal universality; patrimony is an attribute of personality (Stoica, 2017, p. 8)), being the one that, according to the provisions of Point 102 Paragraph (11) of the Methodological Norms for the application of the Fiscal Code has the obligation to issue invoices to the beneficiaries and to collect the tax in case of taxable operations resulting from the association. Article 31 Paragraph (1) of the Civil Code provides that "any natural person or legal person is the owner of a patrimony that includes all the rights and debts that can be valued in money and belong to it".

The full value of the raw materials and embedded services purchased by venturer $B$ related to the association is paid by its leading partner from the proceeds obtained from the sale of jointly made products.

The exception to this rule is found in the provisions of Point 102 Paragraph (5) of the Methodological Norms for the application of Article 321 Paragraph (5) of the Fiscal Code, stating that it is not considered as payment 
only for the goods/services referred to in Paragraphs (3) and (4), i.e. only for the goods which are made available to the association by its members without payment, as a contribution to the association within the limit of the participation share established by agreement, the distribution of the association's incomes being on a cost claim basis, within the limit of the participation share established by agreement, by the managing venturer to the members of the association. As long as the costs incurred are reimbursed to venturer $B$ in exchange for the transfer of ownership of raw materials and utilities to venturer $A$, the operation falls within the scope of VAT.

Certainly, the venturer B maintains the right to deduct the VAT entered in the purchase invoices related to the association in the situation provided by the provisions of Point 102 Paragraph (3), for the goods that are made available to the association by its members without payment, as a contribution to the association within the limit of the participation share established by agreement. This right is confirmed by the provisions of Point 102 Paragraph (9) of the norms: "For the acquisitions of goods provided in Paragraph (3), other than the capital goods for which the provisions of Paragraphs (12)-(16) apply, as well as for the acquisitions necessary to perform the services provided in Paragraph (5), the members of the association may exercise their right of deduction as follows: a) if the delivery of goods/services to third parties carried out by the association involves exclusively operations giving entitlement to deduction, the right of deduction shall be exercised in full.". We notice that the fulfilment of the substantive condition established by the provisions of Article 297 Paragraph (4) Letter a) of the Fiscal Code is preserved, namely that the purchased goods are intended for use for taxable purposes.

Returning to the provisions of Point 102 Paragraph (3) of the Methodological Norms for the application of Article 321 Paragraph (5) of the Fiscal Code, we show that the provisions of Article 1952 of the Civil Code cannot be ignored and that each time the goods are made available to the association by its members without payment, as a contribution to the association within the limit of the participation share established by agreement, it must also take into account these provisions of common law from the fiscal point of view.

In this regard we also mention the case-law of the High Court of Cassation and Justice: "The joint venture agreement [...] concerns the establishment of a company without legal personality; the goods brought by the venturers do not form a share capital, they have the right to be returned the goods for which they have not lost their property right upon termination of the association." (Decision No. 132/2011 of the High Court of Cassation and Justice, Commercial Chamber). The provision of goods to the association by the associated persons has the significance of bringing the goods for the accomplishment of the object of the association, not necessarily implying a transfer of rights. As mentioned in the literature, "it is not necessary to transfer the right of property or use, but only a special assignment of the goods will be achieved" (Cărpenaru, 2009, p. 500).

The provisions of Article 1952 of the Civil Code establish a rule and two deviations from the general legal regime of the contributions of the venturers in a joint venture agreement.

The rule is established by Paragraph (1) and enshrines the fact that the venturers remain the owners of the goods made available to the association. We notice that the provisions of Point 102 Paragraph (3) of the Methodological Norms for the application of Article 321 Paragraph (5) of the Fiscal Code are in compliance with the rule on the regime of contributions under common law, in the sense that the assets that are made available to the association by its members without payment, as a contribution to the association within the limit of the participation share established by agreement, does not constitute delivery of goods with payment within the meaning of Article 270 of the Fiscal Code, according to which "the delivery of goods is the transfer of the right to dispose of the goods as an owner". The immediate consequence is that these operations by which it is performed a special assignment of the respective goods do not constitute operations within the scope of the VAT. The classification as operations outside the scope of VAT, which leaves no doubt, refers to the operations of delivery to itself defined by Article 266 "Significance of certain terms and expressions" Paragraph (1) of the Fiscal Code. 
Thus, VAT is not due for the operations through which the purchased goods or products (for which the venturers remain owners) are made available to the association by its members without payment, as a contribution to the association within the limit of the participation share established by agreement.

The two derogations from the provisions of Paragraph (1) of Article 1952 of the Civil Code, regarding the legal regime of contributions, concern the assumption that the goods brought as a contribution in association become the common property of the venturers, as well as the transfer of the goods brought as a contribution by an venturer in the property of another venturer, both operations within the scope of VAT.

Finally, we cannot fail to note that the contribution considered as an obligation to bring a good in an association is totally opposite to the capital contribution to companies with legal personality, where the transfer of a property right over the assets from the partner/shareholder to the company actually takes place. In the case of joint ventures, the obligation is fulfilled, in principle, by bringing into use the good, an operation that is not subject to indirect taxation (VAT).

\section{References}

1. Cărpenaru, S.D. (2009), Tratat de drept comercial român, Editura Universul Juridic, Bucureşti.

2. Ciutacu, F. (2001), Drept comercial. Culegere de spețe, Editura LVS Crepuscul, Ploieşti.

3. Pleșea, D. (2010), Contabilitatea decontărilor din operații în participație, Contabilitatea, expertiza şi auditul afacerilor, No. 3, pp. 36-40.

4. Stoica, V. (2017), Drept civil. Drepturile reale principale, ediția a III-a, Editura CH Beck, Bucureşti.

5. Codul comercial adnotat, reeditare, Editura Tribuna, Craiova, 1994.

6. Constitution of Romania, republished in Official Gazette No. 767/31.10.2003.

7. Decision No. $713 / 2005$ of the High Court of Cassation and Justice, Commercial Chamber, www.scj.ro.

8. Decision No. 132/2011 of the High Court of Cassation and Justice, Commercial Chamber, www.scj.ro.

9. Decision No. 5543/2015 of the Cluj Court of Appeal, Chamber of Administrative and Fiscal Contentious, www.rolii.ro.

10. Government Decision No. $1 / 2016$ for the approval of the Methodological Norms for the application of the Law No. 227/2015 on the Fiscal Code, Official Gazette No. 22/13.01.2016, as subsequently amended and supplemented.

11. Law No. 287/2009 on the Civil Code, republished in Official Gazette No. 505/15.07.2011, as subsequently amended and supplemented.

12. Law No. 207/2015 on the Code of Fiscal Procedure, Official Gazette No. 547/23.07.2015, as subsequently amended and supplemented.

13. Law No. $227 / 2015$ on the Fiscal Code, Official Gazette No. 688/10.09.2015, as subsequently amended and supplemented.

14. Order of the Minister of Public Finance No. 1802/2014 for the approval of the Accounting regulations regarding the individual annual financial statements and consolidated annual financial statements, Official Gazette No. 963/30.12.2014, as subsequently amended and supplemented.

15. Case-law of the Court of Justice of the European Union. 